\title{
Biomass Production of Cup Plant (Silphium perfoliatum L.) in Response to Variation in Plant Population Density in the North Central USA
}

\author{
Arvid Boe ${ }^{1 *}$, Kenneth A. Albrecht ${ }^{2}$, Paul J. Johnson ${ }^{1,3}$, Jixiang Wu ${ }^{1}$ \\ ${ }^{1}$ Agronomy, Horticulture, and Plant Science Department, South Dakota State University, Brookings, SD, USA \\ ${ }^{2}$ Department of Agronomy, University of Wisconsin, Madison, WI, USA \\ ${ }^{3}$ Insect Biodiversity Laboratory, South Dakota State University, Brookings, SD, USA \\ Email: *arvid.boe@sdstate.edu, kaalbecht@wisc.edu,paul.johnson@sdstate.edu, jixiang.wu@sdstate.edu
}

How to cite this paper: Boe, A., Albrecht, K.A., Johnson, P.J. and $\mathrm{Wu}$, J.X. (2019) Biomass Production of Cup Plant (Silphium perfoliatum L.) in Response to Variation in Plant Population Density in the North Central USA. American Journal of Plant Sciences, 10, 904-910.

https://doi.org/10.4236/ajps.2019.106065

Received: April 24, 2019

Accepted: June 10, 2019

Published: June 13, 2019

Copyright $\odot 2019$ by author(s) and Scientific Research Publishing Inc. This work is licensed under the Creative Commons Attribution International License (CC BY 4.0).

http://creativecommons.org/licenses/by/4.0/

\begin{abstract}
The North American genus Silphium is receiving global attention for its potential in the development of new food, forage, and industrial crops, including cellulosic biomass for biofuel. Little is known about the effect of plant population density on biomass production in large, coarse perennial forbs. Our objective was to evaluate the effect of variation in plant density on biomass production and stand morphology of cup plant (Silphium perfoliatum L.). Plant population densities of 17,000, 34,000, and 68,000 plants ha ${ }^{-1}$ were evaluated for biomass production in a single-harvest per annum system for three years at Brookings, SD and Arlington, WI. Biomass increased linearly by $43 \%$ between the low and high density at Brookings; whereas, at Arlington, response to variation in plant density was year dependent. Shoots plant ${ }^{-1}$ was inversely related to plant density with linear regression explaining $>95 \%$ of the variation. Our results strongly suggested that further studies of effects of plant population density on biomass production in cup plant should include evaluation of, in addition to, densities higher than 68,000 plants ha ${ }^{-1}$.
\end{abstract}

\section{Keywords}

Biofuel, Shoot Density, Shoots Plant ${ }^{-1}$, Stand Morphology, Cup Plant Moth, Eucosma giganteana Riley, Biotic Stress, Abiotic Stress

\section{Introduction}

The genus Silphium is receiving global attention for its potential in the devel- 
opment of new food, forage, and industrial crops [1], including cellulosic biomass for biofuel [2]. High yields of biomass have been achieved for cup plant ( $S$. perfoliatum L.) in Wisconsin [2] and South Dakota [3] indicating its potential for profitable production of forage [4] and/or biofuel in multiple regions of North America. However, no studies have addressed impact of variation in population density on biomass production. Therefore, the objective of this research was to evaluate three plant population densities of cup plant for biomass production for multiple years in the northern Great Plains and Midwest in USA.

\section{Materials and Methods}

Four-month-old greenhouse-grown seedlings of a population of cup plant derived from open pollination between natural populations from Illinois and Minnesota [2] were transplanted in three population densities at Brookings, SD and Arlington WI in June 2010. The soil at Brookings was a McKranz (fine-silty, mixed, superactive, frigid, AericCalciaquolls)-Badger (fine, smectitic, frigid Vertic Aquiaquolls) silty clay loam. It is considered marginal for conventional crop production due to poor drainage. The soil at Arlington was a Huntsville silt loam (fine-silty, mixed, mesic CumulicHapludoll) that was in a low-lying area with a capability class of II because of potential for flood damage from water retention.

At Brookings, no fertilizer was applied during the study. Soil nutrient levels were not determined at planting. The previous crop was soybean [(Glycine max L. Merr.)]. Therefore, we assumed that about $45 \mathrm{~kg} \mathrm{~N} \mathrm{ha}^{-1}$ would be available during the growing season of the establishment year (i.e., 2010) [5]. Historically, the marginal land area was in a long-term wheat (Triticum aestivum L.)-soybean rotation, which was subject to frequent modification by wet soil conditions that precluded timely planting of these grain crops in the spring. At Arlington, the previous crop was alfalfa (Medicago sativa L.). Nitrogen fertilizer was applied annually to both prime and marginal land components at $180 \mathrm{~kg} \mathrm{~N} \mathrm{ha}^{-1}$ in the form of ammonium nitrate. Soil $\mathrm{P}$ and $\mathrm{K}$ were maintained at optimum levels for maize silage production, based on University of Wisconsin recommendations [6].

Plant populations were 17,000,34,000, and 68,000 plants ha ${ }^{-1}$ in $3.1 \mathrm{~m} \times 2.3 \mathrm{~m}$ plots as demonstrated in Figure 1. A randomized complete block design with four replications was employed. The center row of each plot was harvested during mid-September in each of 2011-2013 at Arlington and during mid-October in each of 2011-2013 at Brookings. Plants were harvested at a 10-cm stubble height. Plot wet weights were taken in the field. Grab samples were dried at $60^{\circ} \mathrm{C}$ for 72 hours to determine dry matter concentrations for biomass calculation. Shoots plant ${ }^{-1}$ were counted at harvest for each of 2011 and 2012 at both locations. Weed control was by hand methods.

Biomass yield and shoot density data were analyzed by location using the repeated measures procedure in Statistix 9 [7]. Plant density was the between-subject factor and year was the within-subject factor. Partitioning of plant 


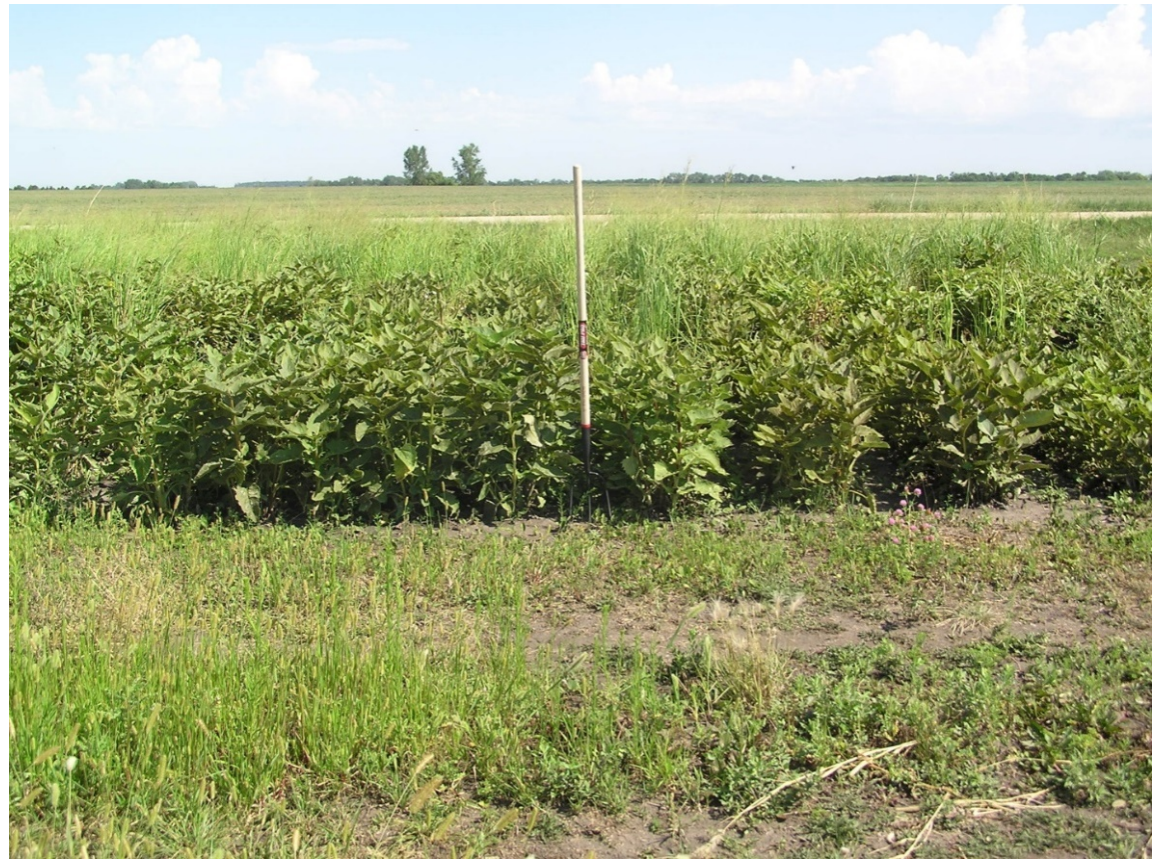

Figure 1. Cup plant population density experiment at Brookings, SD, 2 August 2012. Density treatments are: 68,000 plants ha ${ }^{-1}$ (left of pitchfork); 34,000 plants ha ${ }^{-1}$ (right of pitchfork).

population density sums of squares between linear and non-linear components was accomplished using the polynomial contrasts procedure. Year and plant population density were considered fixed effects; replications were considered random. Growing season monthly (March through September) total precipitation data for Brookings, SD and Arlington, WI during 2011, 2012 and 2013 are presented in Table 1.

\section{Results}

At Brookings, significant differences were found among populations $(\mathrm{P}<0.05)$ and among years $(\mathrm{P}<0.01)$ for biomass production (Figure 2$)$. The population $x$ year interaction mean square was not significant $(P=0.07)$. Annual means ranged from $1.62 \mathrm{Mg} \cdot \mathrm{ha}^{-1}$ in 2012 to $7.45 \mathrm{Mg} \cdot \mathrm{ha}^{-1}$ in 2011. The linear regression model accounted for $99 \%$ of the population density sums of squares. The increase in biomass yield in response to increase in population was $43 \%$ between the low and high plant densities (Figure 2).

A significant $(\mathrm{P}<0.01)$ population $\times$ year interaction occurred for biomass production at Arlington (Figure 3). No differences occurred among populations in either 2011 or 2013; however, the difference between the high $\left(14.23 \mathrm{Mg} \cdot \mathrm{ha}^{-1}\right)$ and low (10.82 Mg.ha $\left.{ }^{-1}\right)$ densities was significant in 2012.

At Brookings, highly significant $(\mathrm{P}<0.01)$ differences occurred between years and among populations for shoots plant ${ }^{-1}$, which increased by nearly $100 \%$ between 2011 (6.6 shoots plant $\left.{ }^{-1}\right)$ and 2012 (12.7 shoots plant $\left.{ }^{-1}\right)$. Linear regression sums of squares accounted for $95 \%$ of the total population sums of squares, with 


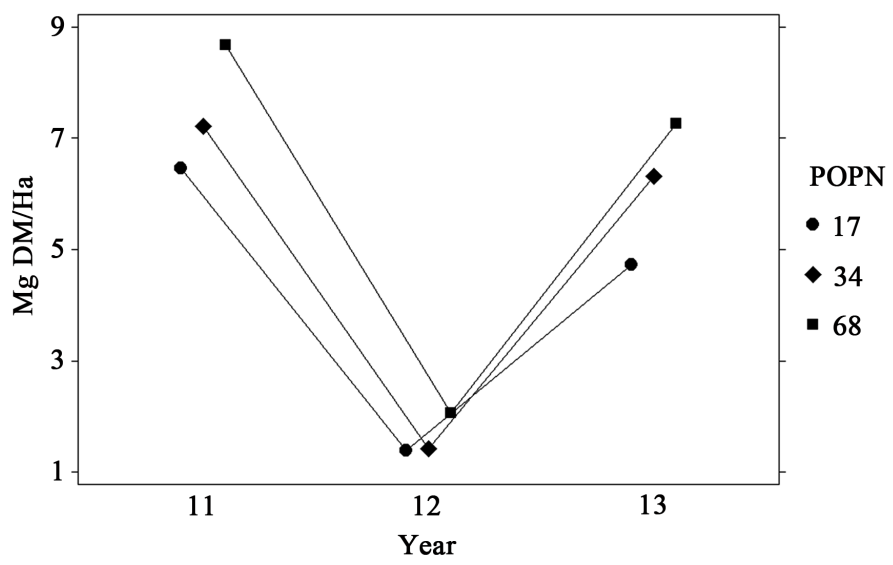

Figure 2. Mean biomass production, for three population (POPN) densities $(17=17,000$, $34=34,000$, and $68=68,000$ plants $\mathrm{ha}^{-1}$ ) of cup plant harvested in October in each of 2011, 2012, and 2013 at Brookings, SD.

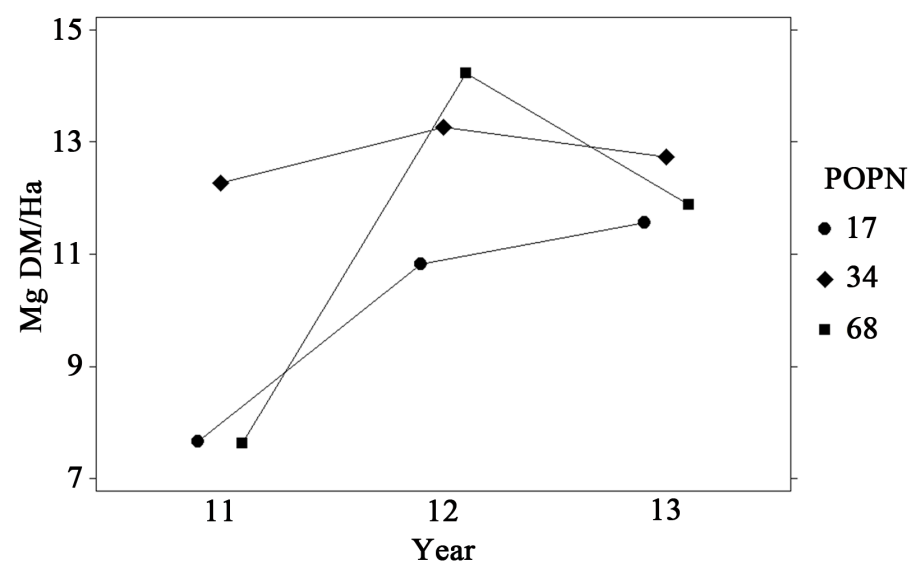

Figure 3. Population $\times$ year interaction for mean biomass production, for three population $(\mathrm{POPN})$ densities $\left(17=17,000,34=34,000\right.$, and $68=68,000$ plants ha $\left.^{-1}\right)$ of cup plant harvested in September in each of 2011, 2012, and 2013 at Arlington, WI.

Table 1. Monthly growing season total precipitation (cm) during 2011, 2012, and 2013 compared with 30-year averages for Brookings, SD and Arlington, WI.

\begin{tabular}{ccccccccc}
\hline & Mar & Apr & May & Jun & Jul & Aug & Sep & Total \\
\hline Brookings & & & & & & & & \\
\hline 2011 & 2.0 & 6.6 & 15.7 & 10.2 & 12.4 & 3.8 & 0.2 & 51.2 \\
2012 & 1.4 & 6.8 & 17.5 & 4.1 & 3.5 & 6.3 & 1.8 & 41.4 \\
2013 & 2.5 & 6.6 & 7.6 & 15.0 & 9.1 & 3.8 & 5.8 & 50.4 \\
30-year & 2.9 & 5.3 & 7.4 & 10.9 & 8.4 & 7.9 & 5.3 & 48.1 \\
Arlington & & & & & & & & \\
2011 & 8.6 & 8.9 & 5.6 & 10.4 & 6.3 & 3.8 & 9.9 & 53.5 \\
2012 & 6.1 & 7.9 & 7.4 & 0.8 & 10.9 & 7.4 & 2.8 & 43.3 \\
2013 & 5.8 & 13.7 & 15.2 & 19.0 & 7.6 & 4.6 & 7.6 & 73.5 \\
30-year & 4.8 & 8.9 & 9.4 & 11.9 & 10.7 & 9.9 & 8.9 & 64.5 \\
\hline
\end{tabular}




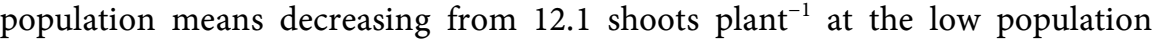
$\left(17,000\right.$ plants $\left.\mathrm{ha}^{-1}\right)$ to 7.4 shoots plant ${ }^{-1}$ at the high population $(68,000$ plants $\left.\mathrm{ha}^{-1}\right)$.

At Arlington, a significant population $\times$ year interaction occurred for shoots plant $^{-1}$. Although mean shoots plant ${ }^{-1}$ more than doubled between 2011 and 2012, populations failed to rank the same across years (Figure 4).

\section{Discussion}

Temporal variations in abiotic and biotic factors had large impacts on biomass production of cup plant populations in the northern Great Plains. In South Dakota, as demonstrated in Figure 1, a severe drought (growing season precipitation was $38 \%$ of the 30 -year average) that coincided with inordinately heavy apical meristem infestation ( $>90 \%$ ) by the larvae of the cup plant moth (Eucosma giganteana Riley) in 2012 resulted in biomass yields less than 25\% of those of each of the bracketing years (i.e., 2011 and 2013), which had more favorable distributions and amounts of precipitation (Table 1). However, the resiliency of cup plant was demonstrated by its ability to recover from abiotic and biotic stresses in 2012 with a 3.5-fold increase in biomass production in 2013, in response to improved moisture and reduced insect pressure [2].

On the other hand, because of greater rainfall and the soil type and site near a marsh at Arlington, moisture was not considered to be limiting in any year contributing to substantially greater yields at Arlington than at Brookings in 2012 and 2013. Larvae of the cup plant moth and Uroleucon sp. aphids were observed in patchy distribution in the plot area, contributing to variability. Minor damage from wild turkeys (Meleagris gallopavo L.) and white tail deer (Odocoileus virginianus Zimmermann) early in each season was also observed. Stem and leaf rust (Puccinia silphii Schwein.) was observed on some plants, causing stems to lodge at the soil surface long before harvest, and these were not included in harvested biomass or stem counts.

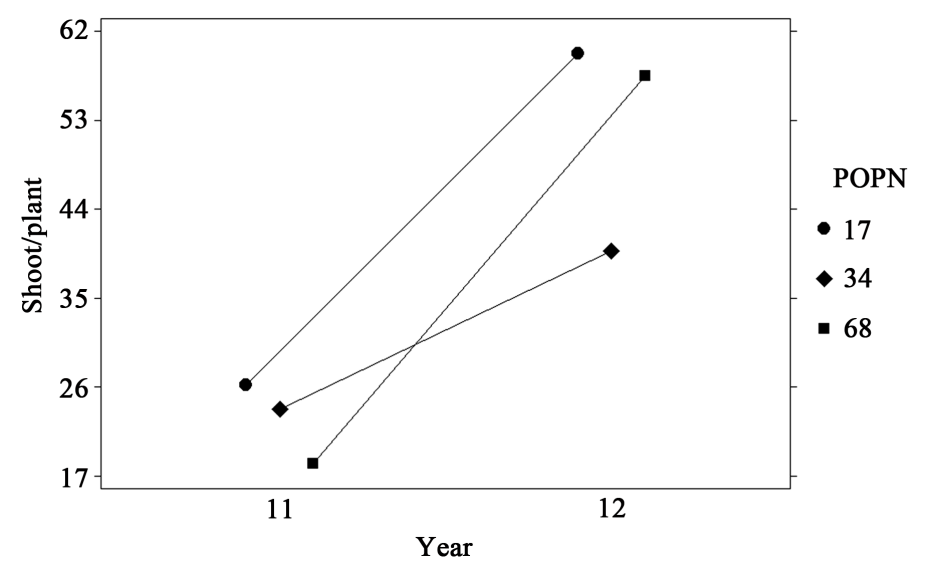

Figure 4. Population $\times$ year interaction for mean shoots plant ${ }^{-1}$ for three population (POPN) densities $\left(17=17,000,34=34,000\right.$, and $68=68,000$ plants ha $\left.{ }^{-1}\right)$ of cup plant at the end of the second (2011) and third (2012) growing seasons at Arlington, WI. 
Only a few studies have evaluated biomass production of cup plant in replicated multi-year trials (e.g., [2]). In each, a single population density was employed. However, these studies demonstrated that cup plant can be highly productive across a wide range of plant population densities. For example, in the USA Albrecht and Goldstein [4] reported yields of $11 \mathrm{Mg} \cdot \mathrm{ha}^{-1}$ from 10,000 plants $\mathrm{ha}^{-1}$ in Wisconsin, Zilverberg et al. [3] reported $25 \mathrm{Mg} \cdot \mathrm{ha}^{-1}$ from 110,000 plants ha ${ }^{-1}$ in South Dakota, and Asseffa et al. [2] observed $10.5 \mathrm{Mg} \cdot \mathrm{ha}^{-1}$ from 28,000 plants ha ${ }^{-1}$ in South Dakota. In Europe, Wever et al. [8] reported yields of 17.2 Mg.ha ${ }^{-1}$ from 40,000 plants ha ${ }^{-1}$ in Germany, and Šiaudinis et al. [9] achieved 21.9 Mg.ha ${ }^{-1}$ from 20,000 plants $\mathrm{ha}^{-1}$ in Lithuania.

To the best of our knowledge, this study was the first of its kind to investigate the effect of variation in plant population density on biomass production of a large perennial that had demonstrated high biomass production and associated enhancement of ecosystem goods and services in the northern Great Plains [3] and Midwest [4]. In its natural environment, we have observed cup plant occurring in relatively dense stands or in isolated clumps. Its growth habit tends to be caudexal and very erect. Individual proaxes produce three short rhizomes during autumn; generally, only one or two produces a new shoot the following spring (A. Boe, unpublished data).

The advantage of increasing population density as a cultural practice to increase biomass production of cup plant was more evident at Brookings than at Arlington. However, breaking down the population $\times$ year interaction for biomass production at Arlington, indicated no advantage for the low population density; whereas, depending on temporal variation, the high population density was superior. These results suggested, since $99 \%$ of the variation for biomass production among the three plant population densities could be explained by linear regression, that further studies should be conducted to include plant population densities greater than the highest (i.e., 68,000 plants ha ${ }^{-1}$ ) evaluated in this study.

\section{Acknowledgements}

This research was supported by funding from the North Central Regional Sun Grant Center at South Dakota State University through US Department of Energy Bioenergy Technologies Office under award numbers DE-FG36-08G088073 and SA1500640. It was also partially supported the USDA-NIFA Hatch Project under award number 1005459.

\section{Conflicts of Interest}

The authors declare no conflicts of interest regarding the publication of this paper.

\section{References}

[1] Van Tassel, D.L., Albrecht, K.A., Bever, J.D., Boe, A.A., Brandvain, Y., Crews, T.E., 
Gansberger, M., Gerstberger, P., Gonzalez-Paleo, L., Hulke, B.S., Kane, N.C., Johnson, P.J., Pestsova, E.G., Risso, V.D.P., Prasifka, J.R., Ravetta, D.A., Schlautman, B., Sheaffer, C.C., Smith, K.P., Speranza, P.R., Turner, M.K., Vilela, A.E., von Gehren, P. and Wever, C. (2017) Accelerating Silphium Domestication: An Opportunity to Develop New Crop Ideotypes and Breeding Strategies Informed by Multiple Disciplines. Crop Science, 57, 1274-1284. https://doi.org/10.2135/cropsci2016.10.0834

[2] Assefa, T., Wu, J.X., Albrecht, K.A., Johnson, P.J. and Boe, A. (2015) Genetic Variation for Biomass and Related Morphological Traits in Cup Plant (Silphium perfoliatum L.). American Journal of Plant Sciences, 6, 1098-1108.

https://doi.org/10.4236/ajps.2015.68114

[3] Zilverberg, C.J., Teoh, K., Boe, A., Johnson, W.C. and Owens, V. (2016) Strategic Use of Native Species on Environmental Gradients Increases Diversity and Biomass Relative to Switchgrass Monocultures. Agiculture, Ecosystems, and Environment, 215, 110-121. https://doi.org/10.1016/j.agee.2015.09.006

[4] Albrecht, K.A. and Goldstein, W. (1997) Silphium perfoliatum: A North American Prairie Plant with Potential as a Forage Crop. The XVIII International Grassland Congress, Winnipeg.

[5] Hoeft, R.G., Nafziger, E.D., Johnson, R.R. and Aldrich, S.R. (2000) Modern Corn and Soybean Production. MCSP Publications, Champaign.

[6] Laboski, C.A.M. and Peters, J.B. (2012) Nutrient Application Guidelines for Field, Vegetable, and Fruit Crops in Wisconsin. University of Wisconsin Extension Bulletin A2809, University of Wisconsin Cooperative Extension Service, Madison.

[7] Statistix (2009) Statistix 9: Analytical Software Tallahassee, FL.

[8] Wever, C., Höller M., Becker, L., Biertümpfel, A., Köhler, J., van Inghelandt, D., Westhoff, P., Pude, R. and Pestsova, E. (2019) Towards High-Biomass Yielding Bioenergy Crop Silphium perfoliatum L.: Phenotypic and Genotypic Evaluation of Five Cultivated Populations. Biomass and Bioenergy, 124, 102-113. https://doi.org/10.1016/j.biombioe.2019.03.016

[9] Šiaudinis, G., Jasinskas, A., Šlepetienè, A. and Karčauskienè, D. (2012) The Evaluation of Biomass and Energy Productivity of Common Mugwort (Artemisia vulgaris L.) and Cup Plant (Silphium perfoliatum L.) in Albeluvisol. Zemdirbyste Agriculture, 99, 357-362. 